\title{
Alignment of Quality Management in SMEs with the Market Performance
}

\author{
Yslene Rocha Kachba', André Mathias Souza Plath², Marcelo Gomes Gitirana Ferreira², \\ Fernando Antonio Forcellini ${ }^{4}$
}

\begin{abstract}
The purpose of this research is to relate competitiveness through productivity on Small and Medium Enterprises (SMEs) with the level of quality that these companies are and the market segment they serve. The methodology used was a multiple case study using questionnaires and systematic observations in SMEs. Results showed that the quality of the companies surveyed is determined by the market segment in which they operate. Quality management is based on the end customer and the view of entrepreneurs look beyond the premises of their companies. The importance of this research is to relate the market segment with the quality level used in SMEs, a strategy required for the current competitiveness.
\end{abstract}

Keywords: quality management; market segment; competitiveness.

\footnotetext{
1,2 Department of Textile Engineering, Federal University of Parana technological,Apucarana, PR, Brazil, 868I2-460, phone \# $00+55+(43)$ 3425-6460, email:yslener@utfpr.edu.br, dgui.plath@aol.com.br

${ }^{3}$ Department of Design, State University of Santa Catarina, Florianopolis city, SC, Brazil, 888035-00I, phone \# 00 + 55 + (48) 332I-8000, email: marcelo,gitirana@gmail.com

${ }^{4}$ Department of Production Engineering, Federal University of Santa Catarina, Florianópolis city, SC, Brazil, 88040-970, phone \# 00 + 55 + (48) 372 I-7 I04,email: forcellini@deps.edu.br
}

ISSN: 07 I8-2724. (http://www.jotmi.org)

Journal of Technology Management \& Innovation (C) Universidad Alberto Hurtado, Facultad de Economía y Negocios. 


\section{Introduction}

The global market and the competitive textile industry is in need of a greater variety and product differentiation, lower prices and higher levels of quality in its products and processes. The Brazilian textile sector generated 264,347 direct jobs in $201 \mathrm{I}$ and produced around 9.8 billion pieces yearly (IEMI, 20I I).These data highlight the importance of the textile sector for the economy, especially because of its significant amount of workforce spread in different companies and regions of the country, mostly made up of Small and Medium Enterprises (SMEs).

Competition with the Asian markets that produce textiles at lower prices than the Brazilian products increasingly required technology management and innovative products and processes in SMEs. Because of the intensification of the Asian Products access in the Brazilian market over the last decade, Brazilian SMEs started to organize themselves in clusters, or Local Productive Arrangements (LPAs). This geographical proximity may minimize costs and enable an increased division of labor and specialization inside the companies, in order to improve the sectors of development, production, design, marketing, quality, flexibility, among others.

Quality is an essential factor for the competitiveness of SMEs and the pursuit for total quality leads companies to improve their processes and products, and consequently make them become competitive in the market they serve. However, presenting a culture focused on a participatory and quality-oriented management aimed at the customer is an arduous and difficult task to achieve, particularly in SMEs (Taddese and Osada, 20I0). Within this context, the objective of this research is to relate the competitiveness and productivity of companies in the cluster of the cap production LPAs with the level of quality where these companies are. To consolidate the analysis, this survey starts from the following hypotheses:

$\mathrm{HO}$ - The higher the quality level of the company, the greater their perception to determine the value for the end customer and all stakeholders.

$\mathrm{HI}$ - SMEs that operate in the marketing section of the market presented a management level of operational quality.

$\mathrm{H} 2$ - Those SMEs classified in a tactical level of quality operated in the market section of private label.

$\mathrm{H} 3$ - The innovation quality level will be found out in companies that operate in the market with their own brand.

Quality management and its systematization

Quality management has a changing concept, and it is also dependant on the system and the culture it belongs to. In a company, the concept of quality management can be aimed at the values for the end costumer, at the quality of the production process, and even at the price of the product. How- ever, quality management develops in companies according to their need for competition in the market where it operates (Paladini, 2009). Thus, the total quality management aims to perform all of its actions towards quality, mutually approaching social and technical aspects that involve a system, whether it is productive or not.

The technical aspects in quality management reflect the orientation for improvement in methods and operations and the demand for a systematic process that enables the constant improvement of goods and services to customers. In another context, there is the social aspect that focuses on human resource management and emphasizes leadership, teamwork, training and commitment of employees (Brennam and Vecchi, 20II).The total quality management (TQM) is a systematic improvement of the quality approach to the whole company for the purpose of improvement in terms of quality, productivity, profitability and shareholders for business and customer satisfaction (Sadikoglu and Zehir, 2010). The quality of companies is currently systematized by Paladini (2009) under three levels: operational, tactical and strategic according to the maturity of quality management that the company presents.

\section{Management of operational quality}

The level of operational quality is diagnosed when companies act toward eliminating their failures and wastes through the controlling and optimization of production processes and the reduction of costs. Usually, the tools and methods used for this company level are:

a) Inspection:This is the first action to take in quality control, according to Paladini (2009) and it is accomplished by means of attributes (a product is defective or not) or variables (quality characteristics in one unit of product are measured on a continuous scale );

b) Seven quality tools: it is a set of devices with a graphic and statistic order for quality control. Among them, we can cite: Pareto diagram, histogram, check sheet, cause and effect diagram, control charts, scatter plot and flowchart (Holschbach and Hofmann, 20 I0, Phan et al., 20I I).

The level of operational quality features other actions and tools that aim at efficiency and effectiveness in the production processes in order to produce goods displaying quality. However, the overall goal is to determine the quality in a company as operational from the moment in which the company does not present a broader view on itself, that is, it focuses only on technical factors of quality management and not on their social ones. 


\section{Tactic Quality Management}

The quality management at the business level is called tactic, based on the quality of human resources training and the quality of the working life, through managerial positions and their own quality management. The rules, tools and actions that are qualified as tactical ones are shown in Table I.

In actions directed to the tactical level, one can note the involvement of managerial measures spread by quality management, whether through the standardization of processes for the achievement of the ISO certification, the application of the weekly five senses present in the $5 \mathrm{~S}$, the introduction of meetings in the quality circles, among others. However, the focus of this level is set on the social aspects, where companies use tools for managing quality that involve the opinions and knowledge of employees and present policies of life quality for them. This happens in order to achieve the quality in production processes, products, and especially the people directly involved in the development and production of these products.

\section{Innovation quality management}

The innovation quality management is a business vision which presents the highest perception of competitiveness to the market due to the fact it presents quality metrics that go beyond the company's facilities. It seeks to find value for the suppliers, the customers and, through social actions, for the external community as a whole. The tools and concepts used by strategic quality are the brand management, the benchmark, the concepts of sustainability, among others (Agus and Hassan, 20I I; Honarpour, Jusoh and Nor, 20I2). For Paladini (2009), innovation quality requires the development of differentiated positions, which create new market positions in society and for the company as well. This level of quality needs different sorts of professionals and entrepreneurs, working or intending to work in the area of quality management with innovative actions.

The benchmarking tool is a innovation quality option that seeks for a reference pattern performed in a comparison

\begin{tabular}{|c|c|c|}
\hline $\begin{array}{l}\text { Tool concept or } \\
\text { philosophy }\end{array}$ & Concept & Authors \\
\hline Quality circles & $\begin{array}{l}\text { The central idea of the circles is the possibility of establishing a positive spirit and mo- } \\
\text { tivation in the group to achieve the essential changes in the culture of the organization. } \\
\text { It is useful to the communication by providing a greater understanding among mem- } \\
\text { bers. These attitudes are demonstrated by means of feelings of unity, loyalty, belonging } \\
\text { to the group, commitment and achievement. }\end{array}$ & $\begin{array}{l}\text { Holschbach and } \\
\text { Hofmann (2010); } \\
\text { Manjudar and } \\
\text { Manorar (201 I); } \\
\text { Phan et al., (2011) }\end{array}$ \\
\hline PDCA & $\begin{array}{l}\text { A tool that serves to integrate systems, process improvements, and is based on four } \\
\text { phases: plan, do, check and action. }\end{array}$ & $\begin{array}{l}\text { Holschbach and } \\
\text { Hofmann (20I0); } \\
\text { Taddese and Osada } \\
(2010)\end{array}$ \\
\hline Kaizen & $\begin{array}{l}\text { It constitutes a continuous improvement through a full stream of value or an individual } \\
\text { process, in order to add greater value with less waste in any production process or } \\
\text { service delivery. }\end{array}$ & $\begin{array}{l}\text { Farris et al. (2009); } \\
\text { Glover et al. (201I) }\end{array}$ \\
\hline $\begin{array}{l}\text { Standardization } \\
\text { by International } \\
\text { Standard Organi- } \\
\text { zation (ISO) }\end{array}$ & $\begin{array}{l}\text { The ISO standardization has been transformed through several reviews to suit market } \\
\text { needs. In summary, the first two versions bring a system heavily focused on the inspec- } \\
\text { tion and bureaucratic controls. The third version has an approach focused on continu- } \\
\text { ous improvement of processes by means of control and management in order to meet } \\
\text { the needs of customers. This led to a reduction of bureaucracy in relation to previous } \\
\text { versions. The fourth version allows the creation of an environmental management } \\
\text { system that will integrate the concept of sustainable production processes by reducing } \\
\text { costs and making a better use of natural resources. }\end{array}$ & $\begin{array}{l}\text { Castka and } \\
\text { Balzarova (2008); } \\
\text { Grael and Oliveira } \\
\text { (20I0); Brendler } \\
\text { and Brandli }(201 \mathrm{I})\end{array}$ \\
\hline Six sigma & $\begin{array}{l}\text { Being an initiative focused on the control of total quality, with emphasis on customer } \\
\text { satisfaction and eliminating errors and failures in production processes. }\end{array}$ & $\begin{array}{l}\text { Santos and Martins } \\
(2010)\end{array}$ \\
\hline $\begin{array}{l}\text { Quality of work- } \\
\text { ing life }\end{array}$ & $\begin{array}{l}\text { The quality of working life afforded to employees of an organization is strongly linked } \\
\text { to their performance. To this end, organizations are investing more in this segment } \\
\text { by investigating factors such as satisfaction, lifestyle, leisure time and lifestyle habits } \\
\text { in order to, by improving the environment and the worker's health, optimize their } \\
\text { production process. }\end{array}$ & $\begin{array}{l}\text { Ouparra and Sy } \\
(2012) ; \text { Menezes } \\
(2012)\end{array}$ \\
\hline
\end{tabular}

Table I - Various tools and philosophies used in tactic quality management

ISSN: 07 I8-2724. (http://www.jotmi.org)

Journal of Technology Management \& Innovation (C) Universidad Alberto Hurtado, Facultad de Economía y Negocios. 
process. The benchmarking success as a model to achieve a competitive advantage depends on the company's ability to creatively adapt the best practices on the market, instead of solely copying them (Dal Forno et al., 2009, Betts et al., 20II).

Another view of the innovation quality is sustainability and mainly the social practices for the community to be carried out by companies. Actions aimed at the economic, social and environmental development of the organization are concepts that are highlighted on the market of today, that is, they are characterized as value for the end customer (Grael et al., 2010). However, there should be a process of interaction within the market and the society via mechanisms that characterize an innovative attitude and generate results that ensure the survival of the company so that the level of quality management can turn into a strategic one (Paladini, 2009). Competitive companies on the market can provide all levels of quality, but quality management tactics and innovation show a greater maturity of the company throughout the participatory culture of all the actors involved directly and indirectly within the company. Those two levels indicate that the company is on the way of getting true value for the end customer, and this feature causes the company to obtain a quality product, a quality process, as well as a quality brand, usually through technology and innovation (Osada and Tadese, 2010).

\section{Textile Sector Characteristics}

Companies in the textile and clothing sectors have product features with a commercial short life cycle, what makes the need for the development of products and production processes run faster, become more flexible and be of a greater distinction as well. Generally, such products are classified as consumer goods, with low technology development, and the size of such businesses is considered in SMEs (Thomassey,
2010; Ciato et al., 20I I).The importance of the textile industry lies in the ability it has to overcome constant crises and on the amount of labor it employs, especially in the clothing industries.

The products of the clothing sector are segmented into: men's wear, women's wear, children's wear and accessories (caps, hats, scarves and so on). These are also classified by the type of raw material used. The textile, clothing and accessories industries on the market of today are divided into three diverse product fronts as follows: Own Label (OL); Promotional Products (P); and Private Label (PL). The textile companies in the OP branch have the product development made in the very own company and it is run by the fashion trends and the analysis for the needs of the final customer. The promotional products are low in cost and intend to promote a brand or service. In the textile sector, they usually are shirts and hats (Brun and Castelli, 2008; Sen, 2008). The PL segment is a phenomenon in which the retailers own the brand and they outsource the production (Garro, 20I I).

\section{Method}

This research has an applied nature, which means it generates methods in order to map out the quality tools used by companies that operate in different segments of the textile market. The problem approach is considered a qualitative one because it does not use either qualitative or statistical parameters to analyze or qualify the data collected.

The exploratory research has as its main objective the improvement of ideas, however, the objective of this paper is to identify and relate the quality management level in companies that operate in different segments of the textile market. Considering the technical procedures adopted, this work is characterized as a multiple case study conducted throughout a questionnaire and the systematic observation of onsite visits in the companies chosen (Miguel et al., 2007).

\begin{tabular}{|l|l|l|l|}
\hline Case & $N^{\circ}$ of Employees & $\begin{array}{l}\text { Monthly production } \\
(\text { pieces })\end{array}$ & Market segment \\
\hline A & 150 & 100.000 & OL \\
\hline B & 7 & 500 & $\mathrm{P}$ \\
\hline C & 28 & 7.000 & $\mathrm{P}$ \\
\hline D & 96 & 80.000 & $\mathrm{PL}$ and P \\
\hline E & 90 & 90.000 & OL, P and PL \\
\hline F & 160 & 125.000 & $\mathrm{P}$ and PL \\
\hline G & 250 & 200.000 & $\mathrm{PL}$ \\
\hline H & 10 & 5.000 & $\mathrm{P}$ \\
\hline I & 94 & 160.000 & $\mathrm{P}$ and PL \\
\hline
\end{tabular}

Table 2 - Characteristics of the studied companies

ISSN: 07 I8-2724. (http://www.jotmi.org)

Journal of Technology Management \& Innovation (C) Universidad Alberto Hurtado, Facultad de Economía y Negocios. 


\section{Popilation and Sample Characterization}

Nowadays, the area surveyed monthly produces about 4 million pieces of caps, bandanas and uniforms, which represent more than half of the national production, generate 4,849 jobs and include 298 establishments in cities located on the northern of Paraná State, which is located in the south of Brazil. In the Apucarana city cluster for caps, there were 88 companies participating on the survey (LPA Network, 20I I). Thus, nine cases of companies that meet the reality of the cluster were obtained as they operate in the three market segments mentioned above, that is, OP, $\mathrm{P}$ and PL. Table 2 describes the characteristics of the companies that participated in the case studies.

The general characteristics of the surveyed companies rank among small and medium enterprises. Most companies operate in the caps and uniforms market in the segments of PL and $P$, they have on average of 14 years of experience in the market and a monthly production of 76.300 pieces.

Data Collection and Analysis Instruments and Methods

The data collection on the companies studied was performed throughout questionnaires and systematic observations in on-site visits at the enterprises, stressing out the use of tools, methods and philosophies of quality management identified in the literature and also observing the point of view belonging to the company. The analysis was performed by the means of quantifying the tools throughout the metric system which was in accordance to the quality level classification given in Table 3 .
The tools, methods or philosophies were classified in the three levels according to the literature. In the questionnaires and on the systematic observations, it was showed the degree in which quality management was used in the company. The weight was a consideration of the need to involve people in the quality activities and the ability to execute such actions. The quality management in each business level was determined by the equation:

$$
\sum_{i: n}^{n} I G Q: F 1 . P 1+F 2 . P 2+F n . P n \ldots .
$$

Where:

$\mathrm{n}$ : number of tools, philosophies or methods that are used in the quality management for the company.

F: usage degree of the tool, philosophy or methodology used in the company.

$\mathrm{P}$ : weight assigned to the tool, philosophy or methodology according to the strategic level and the involvement of employees.

IQM: the index of quality management presented in the company in accordance to the literature.

Thus, after calculating the quality index at the enterprise level, it was compared according to its productivity calculated by:

\begin{tabular}{|c|c|c|c|}
\hline \multirow[b]{2}{*}{ Enterprise level } & \multicolumn{2}{|c|}{ Productivity by each employee $=\frac{\text { Monthly Production }}{\text { Number of employees }}$} & \multirow[b]{2}{*}{ Weight } \\
\hline & Tool, method and philosophy & Punctuation & \\
\hline \multirow[t]{2}{*}{ Operational } & Inspection & $\begin{array}{l}\text { Do not use }(0) \\
\text { Low Use }(0.25) \\
\text { Regularly }(0.5) \\
\text { Always use }(1.0)\end{array}$ & 0.1 \\
\hline & 7 Quality tools & Do not use .... & 0.2 \\
\hline \multirow[t]{5}{*}{ Tactical } & Quality circles & Do not use.... & 0.3 \\
\hline & PDCA & Do not use .... & 0.4 \\
\hline & Kaizen & Do not use .... & I \\
\hline & $\begin{array}{l}\text { International Standard Organization Norms } \\
\text { (ISO) } 9000,9001,14000\end{array}$ & Do not use ... & I \\
\hline & Quality of life at work & Do not use ... & I \\
\hline \multirow[t]{3}{*}{ Innovation } & Sustainability Actions & Do not use ... & 2 \\
\hline & Trademark Management & Do not use ... & 2 \\
\hline & Benchmark & Do not use ... & 2 \\
\hline
\end{tabular}

Table 3 - Data Collection Instruments

ISSN: 07 I8-2724. (http://www.jotmi.org)

Journal of Technology Management \& Innovation (C) Universidad Alberto Hurtado, Facultad de Economía y Negocios. 
Through the alignment of the IQM and the productivity per employee, the competitive metric for the company was determined and it was also pointed out the points that needed to be transformed in the companies of the caps cluster of Apucarana city in terms of good quality practices.

\section{Discussions and Results}

Productivity and IQM in the companies may, according to equation 2, reach the interval from 0 to 10 points. Then, picture I presents the productivity metric related to the number of employees of the company taking into account that the machines at the cap companies LPA in Apucarana have efficiency levels close to the ones verified during the on-site visits.

Companies F, G, and I present the highest levels of productivity and quality management, what represents that such varieties are correlated on PMEs of the LPA researched. Companies $A$ and $B$ have regular rate of productivity and lower IQM because they operate on the promotional caps market segment where client's demand is price and high productivity, without product differentiation consolidating the hypothesis HI. The PL segment demands products with high levels of quality in order to produce certain brands of caps, generally, international sports brands. This group is featured by companies $\mathrm{G}, \mathrm{H}$, and $\mathrm{I}$.
Company $C$ only presents metric of 0.2 IQM and low production. This company only deals with the $\mathrm{P}$ segment and the production manager himself said that this segment is in crisis, but, that the company has no structure of equipment and people to work on the PL segment. At the same productivity and IQM level, we have companies $\mathrm{D}$ and $\mathrm{E}$, which work on market segments $\mathrm{P}$ and $\mathrm{PL}$ for caps and also make uniforms. PME's IQM is subdivided into levels and illustrated on Table 4.

Operational quality management has its focus on the production process and the tools for inspection to determine a standard in order not to present faults. But this management is limited to the operational level; it does not work with management involvement and company culture transformation. The inspection and the quality seven tools are concepts that score for this level and were found on companies B and $C$, again because these companies try to keep in the $\mathrm{P}$ caps market what does not present a differentiated product as a key feature, but the price.

Company $\mathrm{G}$ presents the highest level of tactical quality in all productivity towards the private label market. The company already had ISO 900I and presents four out of the five tools presented on the theoretical reference. All companies that scored on the tactical quality level present its work towards organizational quality of company and products. Companies

\begin{tabular}{|l|l|l|l|l|l|l|l|l|l|}
\hline Level & A & B & C & D & E & F & G & H & I \\
\hline Operational Quality & $0,8 \mathrm{I}$ & 2,72 & 2,72 & 0,85 & $\mathrm{I}, 9 \mathrm{I}$ & $\mathrm{I}, 89$ & $\mathrm{I}, 9 \mathrm{I}$ & $0,9 \mathrm{I}$ & 0,82 \\
\hline Tactical Quality & 0 & 0 & 0 & 3,78 & 2,69 & 3,8 & 4,89 & 2,82 & 4,87 \\
\hline Innovation Quality & $\mathrm{I}, 97$ & 0 & 0 & 2,54 & 0,7 & 2,7 & $\mathrm{I}, 87$ & 0,69 & 2,88 \\
\hline
\end{tabular}

Table 4 - Data Collection Instruments

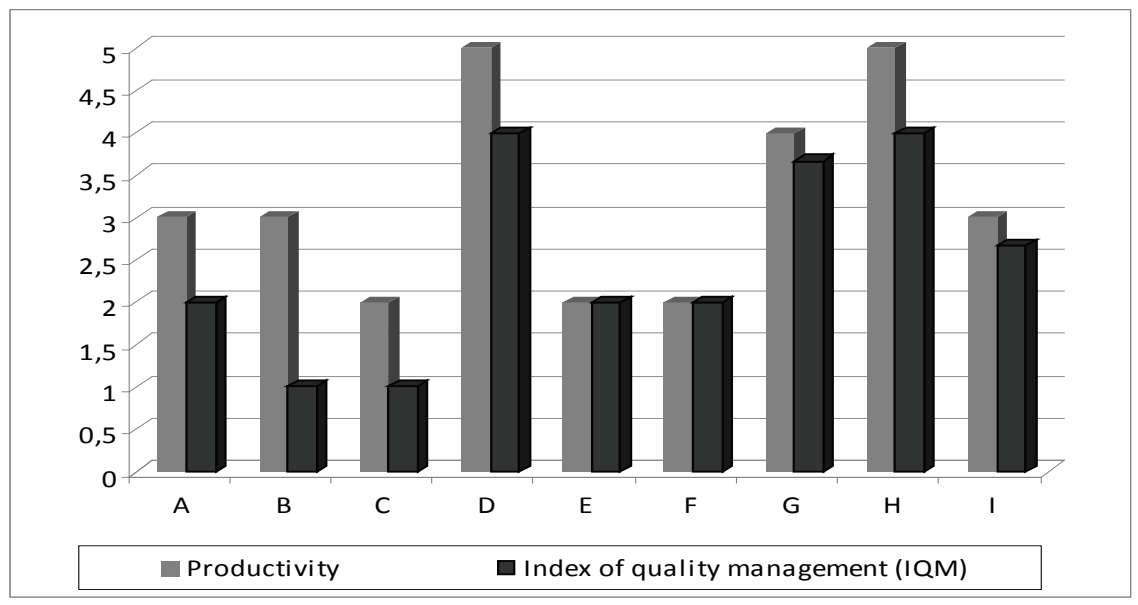

Figure I. Productivity on researched companies

ISSN: 07 I8-2724. (http://www.jotmi.org)

Journal of Technology Management \& Innovation (c) Universidad Alberto Hurtado, Facultad de Economía y Negocios. 
$\mathrm{B}$ and $\mathrm{C}$ act on the $\mathrm{P}$ caps market segment and did not score on this quality level; company $A$ also had level 0 of IQM, however it does not act on the PL segment. Pointing out that the hypothesis $\mathrm{H} 2$ is effective in SMEs because SMEs classified as with quality tactical operate in the PL.

The innovation quality determines the enterprise quality actions turned to the outside of its facilities. The companies that act on its own brand segment tend to structure at innovation quality level. It happens because they need to understand what the client's desires are and what the competitor's strategies through benchmark are in order to create a strong brand with sustainability principles to the society where the company acts. In this context, companies D, F, and I have an average level of innovation quality. However, SMEs that do not act in OL show quality innovation by presenting the non-consolidation of hypothesis 3 . We observe that these companies do not act only in this market segment, but also provide courses in order to strengthen their caps brands and also travel to perform benchmark in companies in China and Italy. The relation between companies' quality and productivity levels by market segment are presented on picture 2 .

The innovation quality is presented by most of the companies researched on the caps LPA. The same companies act on the PL segment. The highest productivity is a feature of the promotional caps companies. However, we observe that innovation quality is far from being a common rate on the PMEs on the LPA of caps. This is because the PL segment does not focuses on the market, as it just makes one process - production - then it does not need to know the final client's needs.

\section{Final considerations}

Quality management is characterized by the market segment need in which the companies act. The known concept that quality is determined by the final client is clear in this research. Thus, companies which act on the caps market with OL tend to apply concepts of innovation quality, on the other hand, companies which work with PL present concepts and tools towards tactical quality. Companies which work with price and productivity on the $\mathrm{P}$ segment only present operational quality level. Consolidating the hypotheses I and 2 proposals in this research that the quality management is entirely linked to the market performance of SMEs. However, SMEs that do not act in OL show quality innovation by presenting the non-consolidation of hypothesis 3 .

Quality levels do not evolve an LPA company may be classified on the innovation quality level with never having passed the operational level. It directly depends on the market vision of the company high board and on the quality culture of the whole organization. Nevertheless, LPA companies, mainly the one which act on the OL market, need a higher number of concepts and tools towards strategy quality in order to become more competitive on the current market and do not compete in the market only by price and high productivity but, with product differentiation.

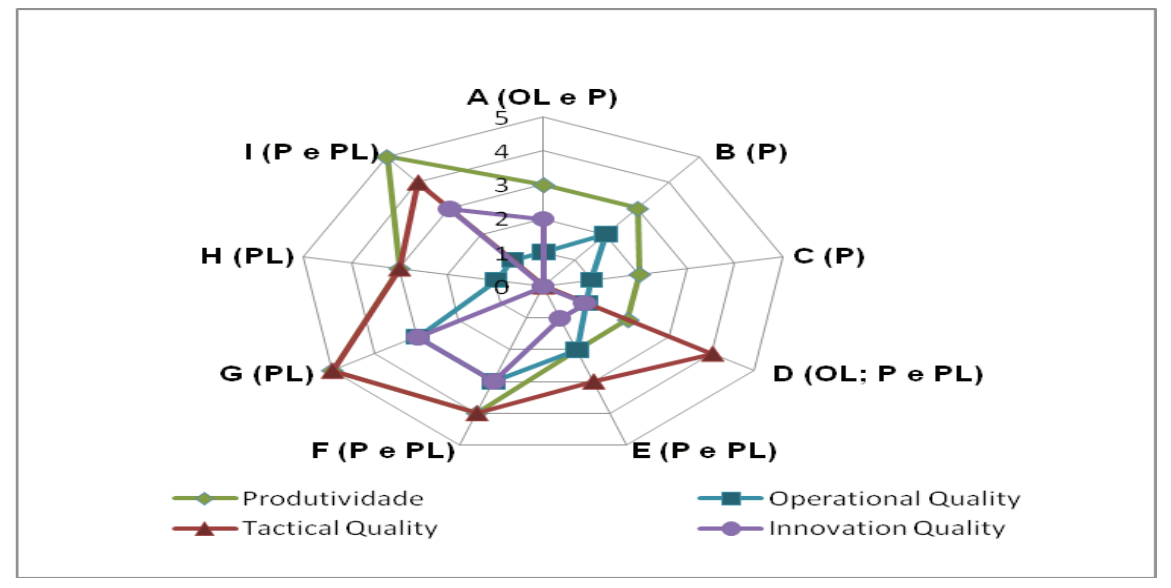

Figure 2. Comparison between levels of quality and productivity management and caps market segment

ISSN: 07I 8-2724. (http://www.jotmi.org)

Journal of Technology Management \& Innovation (C) Universidad Alberto Hurtado, Facultad de Economía y Negocios. 


\section{References}

AGUS, A. HASSAN, Z. (20II). Enhancing production performance and customer performance through total quality management: strategies for competitive advantage. Procedia, 2(4), pp. 1650-1666.

BETTS, A., CROOM, S., LU, D. (20I I). Benchmark to escape from Lake Wobegon. Benchmarking:An International Journal, 8(5), pp. 733-744.

BRENDLER, E. BRANDLI, L. L. (20I I). Integration of environmental management system in quality management system in a garment industry. Gestão \& Produção. 18 (I ), pp. 27-40.

BRUN, A., CASTELLI, C. (2008) Supply chain strategy in the fashion industry: Developing a portfolio model depending on product, retail channel and brand. International Journal Production Economics, II(6), pp. |69-|8I.

CASTKA, P., BALZAROVA, M. (2008). The impact of ISO 9000 and ISO 14000 on standardisation of social responsibility-an inside perspective. International Journal Production Economics, II (3), pp. 74-87.

CIATO, F., CARIDI, M., CASTELLI, C., GOLINI, R. (20II). Supply chain management in the luxury industry: a fist classification of companies and their strategies. International Journal Production Economics, 13(3), pp. 622-622.

DAL FORNO, A. J., BUSON, M.A., SHUCH, C. G., FORCELLINI, F. A., FERREIRA, M. G. (2009). The process of product development from the perspective lean: the variable product benchmark lean. Revista Gestão Industrial, 5 (2), pp. 99-II 6.

FARRIS, A. J., EILEEN, M.V.A., DOOLEN, T.L., WORLEY, J. (2009). Critical success factors for human resource outcomes in Kaizen events: An empirical study. International Journal Production Economics, I I (7), pp. 42-65.

GARRO, A. (20I I). New product demand forecasting and distribution optimization: a case study Zara. 194pp. Master of science in Mechanical Engineering - Sloan School of management (MIT), Cambridge.

GLOVER, W.J., FARRIS, A. J., EILEEN, M.V.A., DOOLEN, T.L. (20II). Critical success factors for the sustainability of Kaizen event human resource outcomes: An empirical study. International Journal Production Economics, 13(2), pp. 197213.

GRAEL, P. F. F., OLIVEIRA, O. J. (20I0). Certifiable environmental management systems and quality: practices for integration in the furniture sector. Revista Produção, 20(I), PP. 30-4I.

ISSN: 07 I8-2724. (http://www.jotmi.org) Journal of Technology Management \& Innovation @ Universidad Alberto Hurtado, Facultad de Economía y Negocios.
HOLSCHBACH, E. HOFMANN, E. (20II). Exploring quality management for business services from a buyer's perspective using multiple case study evidence. International Journal of Operations \& Production Management, 31 (6), Pp. 648685.

HONARPOUR, A.; JUSOH, A.; NOR, K. (20I2). Knowledge management, total quality management and innovation: $A$ new look. Journal of Technology Management \& Innovation, 7(3), pp. 22-31.

IEMI. (20II). Relatório setorial da indústria têxtil brasileira 2010. IEMI: São Paulo.

MANJUDAR, J.P., MANORAR, B.M. (20II). How to make quality circle a success in manufacturing industries. Asian Journal on Quality, 12 (3), p. 244-253.

MENEZES, L.M. (2012). Job satisfaction and quality management: an empirical analysis. International Journal of Operations \& Production Management, 32 (3), pp. 308-328.

MIGUEL, P. A. C. (20I2). Metodologia de pesquisa em engenharia de produção e operações. $2^{\circ}$ Ed. Rio de Janeiro: Elsevier:ABEPRO.

OUPARRA, N.S.; SY, M.V. (20I2). Quality of Work Life Practices in a Multinational Company in Sydney,Australia. Procedia, 40(2), pp. II6-I2I.

PALADINI, E. P. (2009). Gestão estratégica da qualidade: Princípios, métodos e processos. 2.ed. São Paulo:Atlas.

PHAN, A.C., ABDALLAH, A. B., MATSUI, Y. (20II). Quality management practices and competitive performance: Empirical evidence from Japanese manufacturing companies. International Journal Production Economics, I3(3), pp.5 I8-529.

REDE APL. Perfil do Arranjo Produtivo Local de bonés de Apucarana-PR. Disponível em: http://www.redeapl.pr.gov.br/ arquivos/File/Peril_APL_Bone.Apucarana.pdf . [Acesso em May 26, 20II].

SADIKOGLU, E., ZEHIR, C. (20I0). Investigating the effects of innovation and employee performance on the relationship between total quality management practices and firm performance: An empirical study of Turkish firms. International Journal Production Economics, 12(7), pp. 13-26.

SANTOS,A. B.; MARTINS, M. F. (2010). Contribuições do seis sigma: estudos de caso em multinacionais. Revista Produção, 20(I), pp. 42-53, 2010.

SEN, A. (2008). The US fashion industry: a supply chain review. International Journal Production Economics, I I (4), PP. 57|-593. 
TADDESE, F., OSADA, H. (20I0). Process Techno - innovation using TQM in developing countries empirical study of deming prize winners. Journal of Technology Management \& Innovation, 5(2), pp. 47-65.

THOMASSEY, S. (2010). Sales forecasts in clothing industry: The key success factor supply chain management. International Journal of Products Economics. I2(8), pp. 470-483, 2010.

VECCHI, A.; BRENNAN, L. (20II). Quality management: a cross-cultural perspective based on the GLOBE framework. International Journal of Operations \& Production Management, 3 I (5), pp. 527-553. 